Environment Conservation Journal 14(3)131-135, 2013

ISSN 0972-3099 (Print) 2278-5124 (Online)

Abstracted and Indexed

\title{
Impact of physico-chemical parameters on zooplankton diversity of freshwater reservoirs around Amravati District, Maharashtra
}

\author{
K. B. Sangve \\ Received: 25.05 .2013
}

Accepted: 19.8.2013

\begin{abstract}
Impact assessment was carried out on the zooplankton diversity of Pohra, Wadali and Chhatri surface water reservoirs around Amravati with respect to their physico-chemical characteristics. During course of study zooplankton were represented by five major groups i.e. Ostracoda, Rotifera, Cladocera, Protozoa and Copepoda. High value of physico-chemical parameters and low zooplankton diversity were recorded in Chhatri reservoir, moderate in Wadali lake and low value of physico-chemical parameters and high zooplankton diversity were recorded in Pohara lake. The Chhatri reservoir was found to contain most of the pollution indicator species. Wadali reservoir also exhibited few pollution tolerant species. Prominent among them were Ceratodaphnia, Lepadella, Monostyla, Rotarria, Cyclops, Diaptomus and Ectocyclops. The water in all the reservoirs was found to be eutrophic in the order of Pohra > Wadali > Chhatri.
\end{abstract}

Keywords: Physico-chemical parameters, Zooplankton diversity, fresh water reservoirs

\section{Introduction}

Fresh water is one of the most precious commodities for the human beings. In the global perspective, only $0.009 \%$ of the water resources of the earth are stored as fresh water lakes. Amravati is surrounded by a large number of lakes like Wadali, Chhatri, Pohra, Basalapur, Malkhed, Sawangee, Kekatpur, Kondeshwar and many more small and large lakes and reservoirs in the aerials radius of 25 kilometers. The water of these reservoirs is also used for drinking purposes, agriculture and fishery activities. But recently, due to increasing human activities and grazing activities of animals in it, the water is becoming polluted. (Scchidanandmurthy and Yajurvedi, 2006; Parasher et al. 2008). Plankton are the important biotic components of aquatic habitat. They do determine the trophic status and the quality of water and it may affect the fish production.

\section{Material and Methods}

The three reservoirs selected for the present study were "Pohra", "Wadali" and "Chhatri". They all are situated towards the East of Amravati city, India. Reservoir Wadali is situated at $77^{\circ} 48^{\prime}$ E longitudes and $20^{\circ} 55^{\prime} \mathrm{N}$ latitude, reservoir Chhatri

\section{Author's Address}

Department of Zoology, Brijlal Biyani Science College,

Amravati, Maharashtra, India

Email: kiran.sangve@gmail.com is situated at $77^{\circ} 46^{\prime} \mathrm{E}$ longitude and $20^{\circ} 54^{\prime} \mathrm{N}$ latitude and reservoir Pohra is situated at $77^{\circ} 54^{\prime} \mathrm{E}$ longitudes and $20^{\circ} 54^{\prime} \mathrm{N}$ latitude. Water samples for physico-chemical and biological analysis were collected at monthly intervals during January 1996 to December 1996 in between 8 to 10 a.m. Parameters like water temperature $\left({ }^{\circ} \mathrm{c}\right), \mathrm{pH}$, turbidity (NTU), dissolved Oxygen (mg/l) and free $\mathrm{CO}_{2} \quad(\mathrm{mg} / \mathrm{l})$ were measured immediately after collection of samples at the sites by using portable battery operated water analysis kit. Estimation of total alkalinity $(\mathrm{mg} / \mathrm{l})$, total hardness $(\mathrm{mg} / \mathrm{l})$, chlorides $(\mathrm{mg} / \mathrm{l})$, nitrates $(\mathrm{mg} / \mathrm{l})$, phosphates $(\mathrm{mg} / \mathrm{l})$, sulphates $(\mathrm{mg} / \mathrm{l})$, silicates $(\mathrm{mg} / \mathrm{l})$ in collected water samples were carried out in the laboratory within six hours following the standard methods as recommended by APHA (1985). For biological analysis of plankton fifty liter of water samples were filtered through the plankton net of number 25 bottling silk with mesh size $64 \mu \mathrm{m}$ and divided into two parts; one part was fixed with $4 \%$ formalin while other part with Lugol's solution. The identification of phytoplankton was done with the help of keys given by Welch (1948), Trivedi and Goel (1986), APHA (1998) and Khanna and Bhutiani (2003) for physico-chemical parameters. Similarly identification of zooplankton was carried 
out by using key and monographs of Adoni (1985) and APHA (1998).

The Pohra reservoir was quite cool (12.6 to 20.4 ${ }^{\mathrm{O}} \mathrm{C}$ ) in winter season while Chhatri reservoir water was more warm (26.5 to $\left.39.4{ }^{\circ} \mathrm{C}\right)$ in summer season in comparison to Wadali reservoir.The Pohra reservoir water was more transparent (510.6 to $620.2 \mathrm{~cm}$ ) during winter season and Wadali reservoir water was found highly turbid $(62-80$ NTU) during winter season. The increasing order of turbidity was observed to be Pohra reservoir < Chhatri reservoir $<$ Wadali reservoir the $\mathrm{pH}$ was found to be in the order of Chhatri $>$ Wadali $>$ Pohra. In the Chhatri reservoir the $\mathrm{pH}$ was found to

\section{Results and Discussion}

be more alkaline ( 8.4 to 8.9 ) during summer season. It is favourable for the growth of plankton, aquatic plants and fishes. Alkalinity of Wadali reservoir water was found as $188.40-218.60 \mathrm{mg} / \mathrm{l}$ while for Chhatri reservoir it was found as $110.72-140.25$ $\mathrm{mg} / \mathrm{l}$. Sulphate contents in the Chhatri reservoir exhibited $24.62-34.46 \mathrm{mg} / \mathrm{l}$ while a lower range was observed in Pohra $6.84-8.52 \mathrm{mg} / \mathrm{l}$ and Wadali reservoir exhibited high sulphate content i.e. 24.51 $-30.12 \mathrm{mg} / \mathrm{l}$. Phosphate content $(5.6 \mathrm{mg} / \mathrm{l})$ in Chhatri, Pohra 0.002 to $0.027,0.004$ to 0.015 and 0.009 to $0.018 \mathrm{mg} / \mathrm{l}$ (table-1).

\section{Table - 1: Physico-chemical characteristics of Reservoir}

\begin{tabular}{|c|l|c|c|c|}
\hline $\begin{array}{c}\text { Sr. } \\
\text { No. }\end{array}$ & \multicolumn{1}{|c|}{ Parameters } & Pohra & Wadali & Chhatri \\
\hline 1 & Water Temperature $\left({ }^{\circ} \mathrm{C}\right)$ & $24.2-36.2$ & $25.2-37.6$ & $26.5-39.4$ \\
\hline 2 & Transparency $(\mathrm{cm})$ & $510.6-620.2$ & $13.6-18.9$ & $48.6-56.9$ \\
\hline 3 & Turbidity $(\mathrm{NTU})$ & $60-76$ & $62-80$ & $60-78$ \\
\hline 4 & pH & $8.2-8.5$ & $8.5-8.7$ & $8.4-8.9$ \\
\hline 5 & D. O. $(\mathrm{mg} / \mathrm{l})$ & $4.6-8.4$ & $4.3-7.8$ & $4.2-7.6$ \\
\hline 6 & Free $\mathrm{CO}_{2}(\mathrm{mg} / \mathrm{l})$ & $\mathrm{Nil}-28.18$ & Nil -21.6 & Nil -6.3 \\
\hline 7 & Total alkalinity $(\mathrm{mg} / \mathrm{l})$ & $139.12-189.35$ & $188.4-218.6$ & $110.72-140.25$ \\
\hline 8 & Total Hardness $(\mathrm{mg} / \mathrm{l})$ & $168.3-205.4$ & $206.6-295.3$ & $208.95-248.50$ \\
\hline 9 & Chlorides $(\mathrm{mg} / \mathrm{l})$ & $46.2-67.5$ & $108.36-145.32$ & $128.65-262.81$ \\
\hline 10 & Sulphates $(\mathrm{mg} / \mathrm{l})$ & $6.84-8.52$ & $24.62-34.46$ & $24.51-30.12$ \\
\hline 11 & Phosphates $(\mathrm{mg} / \mathrm{l})$ & $0.009-0.018$ & $0.98-1.80$ & $2.5-5.6$ \\
\hline 12 & Silicates $(\mathrm{mg} / \mathrm{l})$ & $0.065-0.186$ & $17.82-19.15$ & $22.25-26.52$ \\
\hline
\end{tabular}

The present investigation was carried out to know the physico-chemical status and its impact on the zooplankton.

During the course of study a total of five major groups of zooplankton i.e Ostracoda, Rotifera, Cladocera, Protozoa and Copepoda were found (table 2 to 6). Ostracods are represented by 2 of copepods and 4 species of protozoans.

Table 2: Diversity of Ostracods in Pohra, Wadali and Chhatri reservoirs

\begin{tabular}{|c|c|c|c|}
\hline Ostracods & POHRA & WADALI & CHHATRI \\
\hline Cyprinotus & + & + & + \\
\hline Cypris & + & + & + \\
\hline Stenocypris & -- & + & + \\
\hline Strandesia & -- & + \\
\hline
\end{tabular}

+: Present, --: Absent genera (Table-2), Rotifers by 13 genera (Table-3), Cladocera by 5 genera (Table-4), Copepods by 3 genera (Table-5) and protozoa by 6 genera (Table6) in the Pohra reservoir. However, Chhatri reservoir exhibited 4 species of ostracods, 18 species of rotifers, 3 species of cladocera, 5 species 
Impact of physico-chemical parameters

Table 3: Diversity of Rotifers in Pohra, Wadali and Chhatri reservoirs

\begin{tabular}{|c|c|c|c|}
\hline Rotifers & POHRA & WADALI & CHHATRI \\
\hline Asplanchna & + & + & + \\
\hline Brachionus angularis & + & + & + \\
\hline B. Calyciflorus & -- & + & + \\
\hline B. Candatus & + & + & + \\
\hline B. Rubens & -- & + & + \\
\hline B. Forficula & -- & + & + \\
\hline B. falcatus & -- & + & + \\
\hline B. quandridentalus & + & + & + \\
\hline B. bidentatus & -- & + & + \\
\hline Cephalodella & -- & -- & + \\
\hline Filinia longiseta & + & + & - \\
\hline F. opeliensis & + & - & - \\
\hline F. ovalis & + & - & - \\
\hline Keratella cochlearis & & - & - \\
\hline K. tropica & + & + & + \\
\hline K. quadratus & + & + & + \\
\hline Lecane luna & + & - & + \\
\hline L. bulla* & - & + & + \\
\hline Lepadella & - & + & + \\
\hline Monostyla* & - & + & + \\
\hline Mytilina & + & + & - \\
\hline Notcholca & + & + & + \\
\hline Rotarria* & - & + & + \\
\hline Testudinella & $\overline{-}$ & + & $\overline{-}$ \\
\hline Trichotria & + & + & - \\
\hline
\end{tabular}

* - Pollution indicator species

+: Present, --: Absent

Table 4: Diversity of Cladocerans in Pohra, Wadali and Chhatri reservoirs

\begin{tabular}{|l|l|l|l|}
\hline Cladocerans & POHRA & WADALI & CHHATRI \\
\hline Alonella & + & + & -- \\
\hline Ceratodaphnia* & -- & + & + \\
\hline Daphnia & + & + & -- \\
\hline Diaphanosoma & + & + & -- \\
\hline Leydigia & -- & -- & + \\
\hline Macrothrix & + & + & -- \\
\hline Moinodaphnia $*$ & -- & + & + \\
\hline Simocephalus & + & + & -- \\
\hline
\end{tabular}

* : Pollution indicator species, + : Present, -- : Absent 
Table 5: Diversity of Copepods in Pohra, Wadali and Chhatri reservoirs

\begin{tabular}{|c|c|c|c|}
\hline Copepods & POHRA & WADALI & CHHATRI \\
\hline Cyclops* & -- & + & + \\
\hline Diaptomus* & -- & + & + \\
\hline Ectocyclops* & -- & + & + \\
\hline Mesocyclops & -- & + & + \\
\hline Nauplius & + & + & + \\
\hline Neodiaptomus & + & + & -- \\
\hline Phyllodiaptomus & + & + & -- \\
\hline Thermocyclop & -- & + & -- \\
\hline
\end{tabular}

* : Pollution indicator species $\quad+$ : Present $\quad$-- : Absent

Table 6 : Diversity of Protozoans in Pohra, Wadali and Chhatri reservoirs

\begin{tabular}{|l|l|l|l|}
\hline Protozoans & POHRA & WADALI & CHHATRI \\
\hline Arcella & + & + & + \\
\hline Centropyxis & + & + & -- \\
\hline Difflugia & + & + & + \\
\hline Euglena & + & + & -- \\
\hline Euglypha & + & -- & - \\
\hline Paramoecium & -- & -- & + \\
\hline Vorticella & + & + & + \\
\hline+ : Present -- Absent &
\end{tabular}

The Chhatri reservoir exhibited the pollution tolerant rotifers like Cephalodella, Lepadella, Monostyla and Rotarria, pollution tolerant cladocerans like Ceratodaphnia and Moinodaphnia, pollution tolerant copepods like Cyclops, Diaptomus and Ectocyclops. Our results are well in agreement with that of Ganpati (1973), Bais and Agarwal (1995) and Cole (1979) who observed these zooplankton in various polluted water bodies. These observations indicate the presence of pollutants in Chhatri reservoir. Chhatri reservoir is situated very near to the MIDC area of the Amravati City, from where the toxic gases might be settling down in the reservoir water and polluting the same.Similarly few pollution indicator species are also recorded from Wadali reservoir (Tables 3 to 5). This could be because of the human activities and entry of domestic sewage in Wadali lake. With respect to the degree of pollution the sequence of the three reservoirs can be given as Chhatri > Wadali > Pohra. However, the Pohra reservoir was found to be non-polluted.

\section{References}

APHA (American Public Health Association) 1998. Standard method for examination of water and wastewater, 20th edition, Washington, DC, USA, P. 4.66-4.69.

Adoni, A.D. 1985. Workbook on Limnology; Indian MAB Committee, Deptt. Of Environment, Govt. of India.

Bais, V.S. and N.C. Agrawal 1995. Comparative study of the zooplanktonic spectrum in the Sagar lake and Military Engineering lake. J. Environ., Biol., 16 (1), 27-32. 
Cole, G.A. 1979. Text book of Limnology. $2^{\text {nd }}$ ed., Mosby, St. Louis., 426 pp.

Ganpati, S.V. 1973. Primary production in the Siddhanath Temple Tank of Baroda, India. Submitted at IBB Aberystuyth Meeting, April-1973.

Parashar, C., N. Verma, S. Dixit and R. Shrivastava 2008. Multivariate analysis of drinking water quality parameters in Bhopal, India. Enviorn. Monit. Assess., 140, 119-122

Sachidanandmurthy, K. L. and H.N. Yajurwedi 2006. A study on physicochemical parameters of an aquaculture body in Mysore city, Karnataka, India. J. Environ. Biol., 27, 615618
Khanna, D.R. and Bhutiani, R. 2003.Limnological characteristic of the river Ganga at Haridwar (Uttaranchal), U.P.J.Zool., Vol. 23(3): 179-183.

Trivedi, R.K. and Goel, P.K. 1986. Chemical and biological methods for water pollution studies. Environmental publications, Karad: 1-250 pp.

Welch, P.S. 1948.Limnological Methods, the Blakiston. Co. Philadelphia, 1-381. 